\title{
Hepatitis B virus markers in prostitutes in Singapore
}

\author{
C L GOH,* A KAMARUDIN,* S H CHAN, + AND V S RAJAN (deceased) \\ From the *Middle Road Hospital, Singapore and the + WHO Immunology Centre, Department of \\ Microbiology, National University of Singapore, Singapore
}

SUMMARY The prevalence of hepatitis B virus markers in 121 men and 239 women prostitutes was studied. Of $33(9 \cdot 7 \%)$ with hepatitis B surface antigen (HBsAg), nine $(27 \cdot 3 \%)$ also had hepatitis Be antigen, which was more prevalent in men than women. Antibodies to HBsAg (antiHBs) and to hepatitis B core antigen (anti-HBc) were found in about $71 \%$ of men and women prostitutes. Hepatitis B virus markers were more prevalent in men than in women prostitutes. Compared with other people, prostitutes had a significantly greater prevalence of hepatitis B virus markers. This study strongly suggested the importance of sexual transmission of infection with hepatitis B virus in a country where infection is endemic.

\section{Introduction}

Viral hepatitis has been shown to be a major health problem throughout the world. ${ }^{1}$ In recent years hepatitis B virus (HBV) has been found to be transmissible not only by the percutaneous route but also through sexual contact. This has been confirmed in numerous epidemiological studies..$^{2-9}$ Most studies on the sexual transmission of HBV have come from developed countries where there is low endemicity, and few studies have been reported from South East Asia where the infection is often endemic. Infection with HBV is common in Singapore, ${ }^{10}{ }^{13}$ partly as a result of vertical transmission of the virus from infected mothers to their newborn children. ${ }^{10-13}$ Epidemiological data have shown that more than $10 \%$ of neonates in Singapore have hepatitis B surface antigen (HBsAg) in their serum. ${ }^{11} 12$

Our study was undertaken to measure the prevalence of HBV markers in prostitutes, and to investigate the role of sexual transmission, in a population that is already highly endemically affected.

\section{Patients, materials, and methods}

We studied 121 men and 239 women prostitutes who attended the sexually transmitted disease clinic at the Middle Road Hospital between January and December 1982. We noted the age, sex, and nationality of each person, but clinical features of hepatitis were not looked for. We collected $10 \mathrm{ml}$ of

Address for reprints: Dr C L Goh, Middle Road Hospital, 250 Middle Road, Singapore 0718

Accepted for publication 15 August 1984 blood from each patient, and the serum samples were stored at $-70^{\circ} \mathrm{C}$ for testing for hepatitis B virus (HBV) markers in batches.

We tested for the following markers: (a) $\mathrm{HBsAg}$ (by the Austria (Abbott Laboratories, Chicago, Illinois, USA) II-125 radioimmunoassay method); (b) antibodies to HBsAg (anti-HBs) (by the Ausab (Abbott) radioimmunoassay method); (c) antibodies to hepatitis B core antigen (anti-HBc) (by the Corab (Abbott) radioimmunoassay method); and (d) hepatitis e antigen (HBeAg) (by the Abbott-HBe radioimmunoassay method).

We compared the prevalence of Hepatitis B virus markers in the serum of prostitutes with their prevalence in other populations in Singapore by a study that had used comparable methods of assay for HBV markers. ${ }^{10}$

\section{Results}

Table I shows the prevalence of HBV markers in prostitutes compared with other people in Singapore. Overall HBsAg was more prevalent in men than women. $\mathrm{HBsAg}$, anti-HBs, and anti-HBc were significantly more prevalent in prostitutes than in other people.

Table II compares the prevalence of HBV markers in different nationalities according to sex. HBsAg was most prevalent in the Chinese followed by the Indians and Malays, but antibodies to HBV were equally prevalent in Chinese and Malays and less common in Indians.

Table III shows the prevalence of $\mathrm{HBeAg}$ in the 33 prostitutes with $\mathrm{HBsAg}$. $\mathrm{HBeAg}$ was more common in the men than the women, but the difference was not significant. 
TABLE I Prevalence of hepatitis B markers in prostitutes compared with other people in Singapore 10

\begin{tabular}{|c|c|c|c|c|c|c|c|c|c|}
\hline \multirow[b]{2}{*}{ Markers } & \multicolumn{3}{|c|}{ No $(\%)$ of men } & \multicolumn{3}{|c|}{ No $(\%)$ of women } & \multicolumn{3}{|c|}{ Total No $(\%)$} \\
\hline & $\begin{array}{l}\text { Prostitutes } \\
(n=121)\end{array}$ & Others & $p$ values & $\begin{array}{l}\text { Prostitutes } \\
(n=239)\end{array}$ & Others & $p$ values & $\begin{array}{l}\text { Prostitutes } \\
(n=360)\end{array}$ & Others & $p$ values \\
\hline $\begin{array}{l}\text { HBsAg } \\
\text { Anti-HBs } \\
\text { Anti-HBc }\end{array}$ & $\begin{array}{r}18(15) \\
104(86) \\
107(88)\end{array}$ & $\begin{array}{c}7 / 112(6) \\
26 / 100(26) \\
35 / 119(29)\end{array}$ & $\begin{array}{l}0.05 \\
0.0001 \\
0.0001\end{array}$ & $\begin{array}{c}15(6) \\
153(64) \\
151(63)\end{array}$ & $\begin{array}{c}12 / 331(4) \\
79 / 286(28) \\
100 / 334(30)\end{array}$ & $\begin{array}{l}\text { NS } \\
0 \cdot 0001 \\
0 \cdot 0001\end{array}$ & $\begin{array}{c}33(9) \\
257(71) \\
285(72)\end{array}$ & $\begin{array}{c}19 / 443(4) \\
105 / 386(27) \\
135 / 453(30)\end{array}$ & $\begin{array}{l}0.005 \\
0.0001 \\
0.0001\end{array}$ \\
\hline
\end{tabular}

$\mathrm{HBsAg}=$ hepatitis B surface antigen.

Anti-HBs = antibody to HBsAg.

Anti-HBc = antibody to hepatitis B core antigen.

\section{Discussion}

Infection with hepatitis B is endemic in South East Asia. The various ways in which the virus is transmitted have been well described. ${ }^{8}$ Despite the various measures taken to reduce the risk of transmission of the virus by the parenteral route, the prevalence of infection with $\mathrm{HBV}$ did not decrease. ${ }^{8}$ Prince et al showed that $55 \%$ of adults with $\mathrm{HBsAg}$ associated hepatitis gave no history of recent transfusion or other parenteral exposure. ${ }^{14}$ Vertical maternal fetal transmission is believed to play an important part in countries where infection is endemic ${ }^{1617}$ and has been shown to have a role, in Singapore, ${ }^{10-13}$ where $4 \cdot 4 \%$ of mothers were carriers of $\mathrm{HBV}$ and $48 \%$ of them transmitted it to their babies. ${ }^{15}$

In our present study $\mathbf{H B s} \mathbf{A g}$ was more prevalent in prostitutes than in the normal population $(9 \% v$ $4 \cdot 3 \%$ ). This further supported the role of sexual transmission as an important source of infection with HBV even in endemically affected populations. On analysing the prevalence of HBsAg according to sex, however, it was greater in men than women prostitutes. Although HBsAg was more prevalent in men prostitutes than in the comparison group, its prevalence was similar among women prostitutes and their age matched comparison group. It appeared that the

TABLE II No (\%) of prostitutes with $\mathrm{HBV}$ markers according to nationality and sex

\begin{tabular}{llllll}
\hline Markers & Sex & Chinese & Malays & Indians & Others \\
\hline HBsAg & & & & & \\
& Men & $15 / 86(17)$ & $2 / 30(7)$ & $1 / 5(20)$ & $0 / 0(0)$ \\
& Women & $12 / 151(8)$ & $3 / 80(4)$ & $0 / 7(0)$ & $0 / 1(0)$ \\
Anti-HBs & Total & $27 / 237(11)$ & $5 / 110(5)$ & $1 / 12(8)$ & $0 / 1(0)$ \\
& Men & $75 / 86(87)$ & $26 / 30(87)$ & $3 / 5(60)$ & $0 / 0(0)$ \\
& Women & $95 / 151(63)$ & $55 / 80(69)$ & $3 / 7(43)$ & $0 / 1(0)$ \\
Anti-HBc & Total & $170 / 237(72)$ & $81 / 110(74)$ & $6 / 12(50)$ & $0 / 1(0)$ \\
& Men & $80 / 86(93)$ & $24 / 30(80)$ & $3 / 5(60)$ & $0 / 0(0)$ \\
& Women & $97 / 151(64)$ & $51 / 80(64)$ & $3 / 7(43)$ & $0 / 0(0)$ \\
& Total & $177 / 237(75)$ & $75 / 110(68)$ & $6 / 12(50)$ & $0 / 1(0)$ \\
\hline
\end{tabular}

HBsAg = hepatitis B surface antigen.

Anti-HBs = antibody to HBsAg.

Anti-HBc $=$ antibody to hepatitis B core antigen. men prostitutes were more susceptible to hepatitis B than the women. This may be related to the sexual habits of homosexual men, who more commonly practise oro-ano-genital sexual activity.

Anti-HBs and anti-HBc were also more prevalent in the prostitutes than in other people. The differences were significant for men as well as women prostitutes ( $p<0.0001$ ). HBV antibodies were about twice as prevalent in prostitutes as in other people, although Fulford $e t$ al have shown the corresponding differences to be 10 -fold. ${ }^{6}$ Both antibodies were present in almost identical numbers, which further supported the role of sexual transmission of infection with HBV. Again HBV antibodies were much more prevalent in men than in women prostitutes, further supporting the predisposition of men to infection with HBV.

Our study showed a difference in predisposition to infection with HBV according to nationality, and the Chinese appeared to be more predisposed to become HBsAg carriers than the Malays or Indians. This finding was also noted in studies on the normal population in Singapore. ${ }^{15}$ Serum antibodies to HBV were about as prevalent in the Chinese as in the Malays, but were less common in the Indians.

$\mathrm{HBeAg}$ is closely associated with active infection, and its persistence in serum may indicate progression to a chronic infectious carrier state. ${ }^{8}$ It is also associated with a high degree of infectivity in patients with $\mathrm{HBsAg} .{ }^{89} \mathrm{HBeAg}$ appeared to be much more prevalent in $\mathrm{HBsAg}$ positive men $(38.9 \%)$ than women $(13 \cdot 3 \%)$ prostitutes. It thus appeared that the men prostitutes formed an important infectious pool for the transmission of HBV. HBsAg positive men prostitutes appeared to be more likely than

TABLE III Prevalence of hepatitis $B$ e antigen ( $\mathrm{HBeAg}$ ) in 33 prostitutes with hepatitis B surface antigen (HBsAg)

\begin{tabular}{lll}
\hline & $\begin{array}{l}\text { No (\%) } \mathrm{HBeAg} \\
\text { positive }\end{array}$ & $\begin{array}{l}\text { No (\%) } \mathrm{HBeAg} \\
\text { negative }\end{array}$ \\
\hline Men & $7(38 \cdot 9)$ & $11(61 \cdot 1)$ \\
Women & $2(13 \cdot 3)$ & $13(86 \cdot 6)$ \\
Total & $9(27 \cdot 3)$ & $24(72 \cdot 7)$ \\
\hline
\end{tabular}


women to carry the e antigen. This finding may indicate an impaired immune response to infection with HBV in men prostitütes. The difference was not significant, however, but this may be due to the very small number of patients available for statistical analysis.

From this study we concluded that sexual transmission of infection with $\mathrm{HBV}$ is important even in countries where such infection is highly endemic. Immunisation against $\mathrm{HBV}$ has been found to be effective ${ }^{1819}$ and should therefore be considered for this high risk group, thus indirectly conferring protection to people exposed to prostitutes. It must be stressed that immunisation has to be carried out before infection for it to be effective, and most prostitutes probably become infected early in their careers. It may become necessary to screen all $\mathrm{HBsAg}$ positive prostitutes for $\mathrm{HBeAg}$ and to discourage them from working because of their infectivity.

\section{References}

1. Szmuness W, Harley H, Ikram H, Stevens C. In: Vyas GN, Cohen SN, Schmid R, eds. Sociodemographic aspects of the epidemiology of hepatitis $B$. Philadelphia: The Franklin Institute Press 1978;297-320.

2. Vahrman J. Transmission of hepatitis. Lancet 1970: ii: 774.

3. Vahrman J. Spread of acute type B hepatitis in London. Lancet 1973; ii: 157.

4. Heathcote J, Sherlock S. Spread of acute type B hepatitis in London. Lancet 1973; i: 1468-70.
5. King AJ. In: Loraine JA, ed. Understanding homosexuality: its biological and psychlogical bases. Lancaster: Medical and Technical Publishing. 1974: 199.

6. Fulford KWM. Australia antigen and antibody among patients attending a clinic for sexually transmitted diseases. Lancet $1973 ; \mathrm{i}: 1470-3$.

7. Coleman JC, Waugh M, Dayton R. Hepatitis B antigen and antibody in a male homosexual population. British Journal of Venereal Diseases 1977; 53:132-4.

8. Caterall RD. Some observations on the epidemiology and transmission of Hepatitis B. British Journal of Venereal Diseases 1978; 54:335-40.

9. Inaba I, Ohkawa R, Matsuura A, Kudoh J, Takamizawa $H$ Sexual transmission of hepatitis B surface antigen. British Journal of Venereal Diseases 1979; 55:366-8.

10. Oon CJ, Chan L, Chan SH, et al. Immune status of various populations to hepatitis B virus in Singapore and a strategy for its prevention and immunoprophylaxis. Dev Biol Stand 1983, 54:295-305.

11. Quak SH, Singh R, Oon CJ, Wong HB. A cross sectional study of hepatitis B immune status in Asian children in Singapore. Ann Trop Paediatr 1982; 2:53-6.

12. Quak SH, Singh R, Oon CJ, Wong HB. The immune status of Singapore children to hepatitis B virus. Aust Paediatr J 1983; 19:100-3.

13. Goh KT. Hepatitis B surveillance in Singapore. Ann Acad Med Singapore 1980;9:136-41.

14. Prince AM, Hargrove RL, Szmuness W, Cherubin CE, Fontana VJ, Jeffries GH. Immunological distinction between infectious and serum hepatitis. N Engl J Med 1970; 282:987-91

15. Chan SH, Tan KL, Goh KT, et al. Maternal-child hepatitis B virus transmission in Singapore. Int J Epidemiol (in press).

16. Gilbert GL. Vertical transmission of hepatitis B: review of the literature and recommendations for management. Med J Aust $1981 ; 1: 280-5$.

17. Stevens CE, Beasley RP, Tsui J, Lee WC. Vertical transmission of hepatitis B in Taiwan. N Engl J Med 1975;292:771-4.

18. Szmuness $\mathrm{W}$, Stevens CE, Harley EJ, et al. Hepatitis B vaccine: demonstration of efficacy in controlled clinical trial in a high risk population in the USA. N Engl J Med 1980; 303: 833-41.

19. Coutinho RA, Lelie N, Albrecht Van Lent $P$, et al. Efficacy of a heat inactivated hepatitis B vaccine in male homosexuals: outcome of a placebo controlled double blind trial. $\mathrm{Br}$ Med $\mathrm{J}$ $1983 ; 286: 1305-8$ 